\title{
BENTUK KELEMBAGAAN DAN POLA PEMBIAYAAN LAND BANKING PUBLIK DI INDONESIA
}

\author{
Institutional Set up and Funding Scheme for Public Land Banking in \\ Indonesia
}

\section{Azhari Pamungkas ${ }^{1}$, Haryo Winarso ${ }^{2}$}

Received: 29 Mei 2017

Accepted: 12 Oktober 2017

\begin{abstract}
Penerapan land banking berpeluang dilakukan di Indonesia sebagaimana keberhasilannya di berbagai negara dalam menyelesaikan berbagai permasalahan terkait lahan. Penelitian ini bertujuan untuk merumuskan bentuk kelembagaan dan pola pembiayaan land banking di Indonesia. Penelitian ini mengadopsi metode Delphi untuk menganalisis pendapat para ahli dengan review literatur dan peraturan perundangan. Penelitian ini merekomendasikan konsep bentuk land banking publik yang terdiri dari perusahaan utama dan perusahaan anak land banking. Perusahaan utama merupakan badan usaha milik daerah (BUMD). Perusahaan anak merupakan badan usaha yang dibentuk bersama oleh BUMD, swasta, masyarakat contributor lahan dan pemerintah daerah. Perusahaan utama bank lahan (BUMD) memiliki tugas untuk mengelola land banking bagi kepentingan umum seperti infastruktur, perumahan rakyat dan fasilitas social sehingga tidak bertujuan mencari keuntungan. Perusahaan anak bertugas mengelola land banking dengan melakukan pengembangan lahan yang keuntungannya dibagi kepada para pemilik saham termasuk kepada BUMD bank lahan.
\end{abstract}

Keyword in Bahasa: land banking, kelembagaan, pembiayaan, Indonesia

\begin{abstract}
The application of land banking is likely to be conducted in Indonesia as well as its success in various countries in solving various land-related problems. This study aims to formulate an institutional set up and funding scheme for land banking in Indonesia. This study utilized an adoption of Delphi method to compile and interprete expert opinions, in addition extensive review of literature and legislations were also conducted. This study recommends the set up of public owned land banking company that consist of main company and subsidiary company. The main company is $100 \%$ owned by the government. The subsidiary company is jointly developed with private sector and community. The main company is assigned to bank land for public purposes (eg. infrastructures, public housing, facilities) and not for profit. The subsidiary company is assigned to bank land for development and giving opportunity the land owners to get share and profit. The set up land bank company is funded by local budget. Profit from the subsidiary company can be reinvented to the main company.
\end{abstract}

Keywords: land banking, institutional set up, funding, Indonesia

\footnotetext{
${ }^{1}$ Staf Pemerintah Kota Metro Lampung

${ }^{2}$ Sekolah Arsitektur, Perencanaan dan Pengembangan Kebijakan (SAPPK) ITB
}

Korespondensi: azhari.mymail@gmail.com 


\section{PENDAHULUAN}

Rencana pola ruang dalam penerapannya menghadapi kekuatan pasar, seperti yang terjadi di DKI Jakarta (Sudianto, 2014). Hal ini dikarenakan pengembangan lahan di Indonesia menggunakan model privat market. Pada kenyataannya pengembangan lahan swasta telah menyebabkan urban sprawl dimana-mana yang tidak dikehendaki oleh perencana (Zulkaidi, dkk , 2007). Di sisi lain, perwujudan struktur ruang melalui pembangunan infrastruktur di Indonesia sering dihadapkan oleh hambatan terbesar yaitu pembebasan lahan (IDB, 2010).

Permasalahan yang sering muncul di Indonesia terkait lahan dan pembangunan akan dapat terselesaikan dengan pemilikan lahan publik. Pemerintah akan memiliki posisi tawar dalam penerapan rencana tata ruang karena memiliki sejumlah lahan ataupun keseluruhan lahan. Pemerintah juga tidak akan menghadapi hambatan pembebasan lahan dalam penyediaan infrastruktur maupun fasilitas publik karena lahannya telah tersedia. Oleh karena terdapat kepastian dalam pembangunan, pemerintah dapat mereduksi pembiayaan infrastruktur. Terakhir, pemerintah lebih bisa memastikan keadilan sosial dalam hal pembangunan (Kivell, 1993).

Pemilikan lahan publik salah satu caranya ialah menggunakan instrumen land banking. Land banking ialah penyimpanan lahan untuk penggunaan di masa mendatang (UNESCAP, 1993). Land banking terbukti telah memberikan manfaat dan kemudahan dalam pembangunan yang ditunjukkan dalam prakteknya di berbagai negara (Limbong, 2013). Oleh karena itu pendekatan cara land banking berpeluang diterapkan pula di Indonesia guna membantu menyelesaikan permasalahan lahan yang menghambat pembangunan berkelanjutan.

Di Indonesia pernah ada badan hukum yang bertindak sebagai land bank yaitu perusahaan tanah dan bangunan. Di DKI Jakarta terdapat PD Pembangunan Sarana Jaya namun skalanya sangat kecil (Oetomo, 1999). Di Surabaya terdapat Yayasan Kas Pembangunan yang saat ini dalam kasus sengketa aset dengan Pemerintah Kota Surabaya (Armanda, 2013). Walaupun demikian perusahaan tanah dan bangunan yang pernah ada di Indonesia fungsi dan perannya sangat kecil sebagai land banking (Oetomo, 1999).

Penelitian atau kajian mengenai land banking publik belum banyak dilakukan di Indonesia terutama berkaitan dengan konsep penerapannya yang disesuaikan dengan konteks yang ada. Muncul pertanyaan penelitian seperti apa peluang penerapan land banking di Indonesia yang terdiri dari pertanyaan mengenai siapa yang berperan melakukan land banking dan bagaimana entitas tersebut melakukan dan membiayai land banking di Indonesia? Tujuan dari penelitian ini adalah untuk merumuskan bentuk kelembagaan dan pola pembiayaan land banking publik di Indonesia. Adapun untuk mencapai tujuan tersebut maka terdapat beberapa sasaran penelitian yang merupakan tahapan dalam mencapai tujuan. Sasaran-sasaran penelitian ini adalah mengeksplorasi preseden praktek land banking dari berbagai negara dan mengambil pelajaran, mengidentifikasi landasan peraturan perundangan Indonesia yang mendukung atau menghambat penerapan land banking publik, dan terakhir merumuskan bentuk kelembagaan dan pola pembiayaan land banking publik di Indonesia.

\section{Pasar Lahan dan Spekulasi}

Dalam berbagai literatur seperti Kivell, (1993), Evans, (2004), maupun Harrison, (2010), menyatakan bahwa pasar lahan merupakan pasar yang tidak efisien. Pasar lahan tidak dapat memenuhi asumsi adanya informasi yang penuh dan seimbang antara pembeli dan penjual yang mengakibatkan harga tidak ditentukan semata-mata oleh jumlah permintaan dan penawaran (Evans, 2004). Karakteristik lahan sebagai produk pasar memiliki keunikan karena tidak ada tanah yang benar-benar identik (Hermit, 2009). Pasar 
properti pun seringkali mengalami bubble yang disebabkan oleh keinginan mencari keuntungan yang dapat berakibat pada inflasi hingga resesi (Harrison, 2010). Proses spekulasi disebabkan oleh asumsi dasar bahwa setiap pemegang lahan selalu berusaha menahan lahannya untuk dijual pada saat yang tepat yakni dengan nilai dan kegunaan yang setinggi-tingginya (Evans, 2004). Proses spekulasi atau harapan ini akan berada pada jalur yang benar bila pemilik, investor dan spekulator berada di sektor publik (Evans, 2004). Hal ini berarti sektor publik ataupun pemerintah perlu melakukan intervensi terhadap pasar lahan termasuk bahkan menjadi spekulator.

\section{Lahan Publik}

Kepemilikan lahan publik memiliki dampak positif yaitu setidaknya dengan tiga argumen (Kivell, 1993). Pertama, kepemilikan lahan publik diperlukan dalam pembangunan agar dapat mendorong pola penggunaan lahan yang sesuai dan efisien, dan pertumbuhan yang terkendali. (Hall, 1975 dan Roberts, 1977 dalam Kivell, 1993). Kehoe, dkk, (1976) dalam Kivell, (1993) menambahkan argumen bahwa kepemilikan lahan publik dapat mengurangi hambatan dalam pengaturan sistem pola ruang. Kedua, kepemilikan lahan publik dapat memberikan keadilan sosial dan memastikan manfaat pengembangan lahan dapat dinikmati bersama bagi masyarakat (Kivell, 1993). Ketiga, kepemilikan lahan publik dapat memudahkan pemerintah dalam penyedian infrastruktur, dan fasilitas publik yang menjadi tanggung jawabnya.

Namun kepemilikan lahan publik juga dikritisi oleh beberapa pihak yang dijelaskan pula ke dalam tiga argumen yaitu inefisiensi birokrasi, monopoli publik yang mengancam hak privat, dan dinamika nilai lahan.

1. Birokrasi masih diragukan untuk dapat memberikan keputusan dengan tepat pada penggunaan lahan sehingga dapat menyebabkan penggunaan lahan yang tidak progresif, tidak sensitif, dan tidak efisien karena perilaku birokrasi (Bryant, 1976 dan Clawson, dalam Kivell, 1993). Sering pula kepemilikan lahan publik, walaupun seimbang dengan privat, disalahkan sebagai penyebab perlambatan pengembangan dan naiknya nilai lahan (Markusen dan Scheffman 1977; Nowlan 1977; Lloyd 1989 dalam Kivell, 1993). Menurut Hamilton dan Baxter , (1977) belum ada bukti yang menunjukan pemerintah dapat menyediakan lahan yang lebih baik maupun lebih murah dan bahkan berpeluang melalukan kesalahan dalam pengelolaan.

2. Monopoli kepemilikan lahan publik dapat mengancam pengusahaan oleh sektor swasta. Robin Ranjack, (2007) menyatakan dalam hasil penelitiannya terhadap 50 kota di dunia bahwa pemilikan lahan publik akan berdampak tentatif positif terhadap pasar lahan apabila hanya sedikit mendominasi. Menurutnya, pemilikan lahan publik yang dominan tidak memberikan dampak yang baik bagi pasar lahan (Rajack, 2007).

3. Carr \& Smith, (1975) menunjukkan bahwa kepemilikan lahan publik tidak serta merta mengurangi kenaikan nilai lahan. Lahan akan dinamis dalam kondisi apapun walaupun dalam kondisi ekonomi campuran (sektor publik dan privat seimbang). Bahkan ada kekhawatiran bahwa institusi pemerintah lambat dalam mengikuti perubahan ekonomi dan politik. Apa yang terjadi di Inggris pada tahun 1970an menunjukkan banyak lahan publik yang terlantar dan dibeli sebelumnya oleh pemerintah dengan nilai yang tinggi karena terdapat booming lahan (Kivell, 1993).

Berdasarkan uraian di atas, dalam menyimpan lahan publik pemerintah harus mempertimbangkan argumen-argumen yang menentang kepemilikan lahan publik sehingga pengelolaannya dapat efisien, tidak mengancam pengusahaan sektor swasta serta tidak terlantar. 


\section{Land Banking}

Oetomo, (1999) membagi land banking ke dalam dua kelompok yaitu konvensional dan non konvensional. Land banking konvensional diartikan sebagai pembelian lahan dalam jumlah besar oleh pemerintah untuk penggunaan di masa mendatang. Di samping konvensional, Oetomo, (1999) menyampaikan bahwa terdapat gagasan baru mengenai land banking yaitu land banking non konvensional dengan istilah lain Cooperative Land banking. Land banking non konvensional merupakan pengembangan konsep land sharing. Pemilik lahan masih memiliki aset dan mendapatkan keuntungan pengembangan dari asetnya.

Land banking atau kegiatan perbankan lahan ialah akuisisi lahan di awal yang manfaat utamanya bagi publik dapat membeli lahan saat murah untuk tujuan publik dan menyediakan seperangkat alat untuk mempengaruhi pola pembangunan agar sesuai dengan tujuan perencanaan (UNESCAP, 1993). Evans, (2004) berpendapat bahwa land banking publik ialah pemilikan lahan oleh pemerintah untuk kemudian dikembangkan, dibangun infrastruktur dan sebagian tanahnya dapat dijual kepada pengembang untuk membiayai pembangunan. Land banking publik memiliki salah satu fungsi yaitu untuk mengontrol urban sprawl (Evans, 2004).

Heins \& Abdelazim, (2014) mendefinisikan land banking sebagai entitas pemerintah atau perusahaan nirlaba publik yang mengkhususkan diri dalam akuisisi properti bermasalah, dengan maksud mengembalikan fungsi produktif, atau sementara memegang dan menyimpan lahan untuk tujuan menstabilkan pasar yang sedang tertekan atau memenuhi penggunaan lahan jangka panjang dan kepentingan masyarakat. Jessica de Wit, (2006) bank lahan yaitu suatu otoritas publik yang diciptakan untuk secara efisien mengelola dan mengembangkan properti sitaan. Land bank itu seperti bank yang menyimpan nilai sampai waktu yang dibutuhkan dan sangat berguna karena pasar lahan yang efisien jarang sekali terjadi. (Alexander, 2008), (Alexander, 2011).

Dari berbagai definisi bank lahan yang disebutkan di atas maka dapat disimpulkan bahwa bank lahan publik ialah sebuah entitas publik atau milik pemerintah yang melakukan akuisisi, penyimpanan, pengelolaan produktifitas dan/ atau pengembangan lahan di kemudian hari agar sesuai dengan tujuan perencanaan pembangunan yang akuisisi lahannya dapat dilakukan secara non-konvensional.

Berdasarkan definisi yang dijelaskan sebelumnya maka proses land banking secara umum ialah akuisisi lahan, penyimpanan lahan (UNESCAP, 1993), pengelolaan produktifitas lahan (Heins \& Abdelazim, 2014) dan atau pengembangan lahan / pembangunan. Limbong, (2013) memiliki pandangan sendiri mengenai mekanisme bank lahan. Menurutnya mekanisme kegiatan bank lahan hanya ada 3 yaitu penyediaan tanah, pematangan tanah dan pendistribusian tanah.

Pada prakteknya, proses land banking akan berbeda pada setiap model pengembangan lahan seperti yang dijelaskan sebelumnya (Jacobs \& van der Krabben, 2013) yaitu :

1. Pada model pengembagan lahan publik komprehensif land banking dilakukan oleh pemerintah dengan mengakuisisi lahan sebesar-besarnya untuk kemudian dibangun infrastruktur dan properti. Land banking sampai pada tahap pengembangan lahan dan menjual properti. Tujuannya adalah untuk memastikan rencana tata ruang dan mendapatkan pemasukan pengganti biaya pembangunan infrastruktur. Namun bank lahan pada model ini membutuhkan modal yang besar.

2. Pada model model pengembangan lahan quasi publik, bank lahan hanya bekerja hingga penyediaan infrastruktur dan pematangan lahan. Karena proses pematangan ini pemerintah menjual lahan kepada swasta dengan menambah keuntungan secukupnya untuk mengganti biaya pematangan. Pengembangan lahan 
atau pembangunan properti selanjutnya dilakukan oleh swasta. Proses land banking pada model ini seperti yang ditulis oleh Limbong, (2013) di atas.

3. Pada negara yang menganut model pengembangan lahan pasar swasta maka land banking dilakukan oleh swasta itu sendiri dengan menyimpan lahan untuk pada waktu yang tepat kemudian dikembangkan. Namun seperti halnya di Amerika Serikat yang menganut model pasar swasta, ternyata terdapat bank lahan publik. Bank lahan Amerika Serikat tidak ikut terjun dalam pasar untuk mengembangkan lahan tetapi hanya mengatasi properti-;properti yang hilang dari pasar karena bermasalah (Alexander, 2011).

Menurut Devoy \& Rodrungrung (tanpa tahun), terdapat dua hal yang dapat menjadi hambatan bagi penerapan land banking yaitu kemauan pemerintah dan sumber pembiayaan. Pemerintah seringkali tidak memiliki kemauan untuk menerapkan land banking. Adapun pembiayaan land banking akan berkompetisi dengan program pemerintah lainnya. Land banking membutuhkan sejumlah besar uang untuk mengakuisisi lahan yang membuat uang tersebut tidak dapat digunakan langsung untuk kegiatan lain yang lebih produktif menggerakan ekonomi.

Land banking yang layak ialah apabila biaya land banking lebih efisien daripada pembebasan lahan saat dilakukan pembangunan. Biaya land banking meliputi akuisisi, perawatan aset, dan bunga modal per tahun. Walaupun demikian, salah satu bukti empiris di Thailand menunjukkan bahwa biaya land banking masih lebih murah daripada pembebasan lahan saat dibutuhkan (National Housing Authority Thailand, 1981 dalam Devoy \& Rodrungrung).

\section{Kelembagaan}

Terdapat 2 sudut pandang tentang kelembagaan yaitu organisasi dan kaidah/aturan. Kedua sudut pandang tersebut digunakan dalam penelitian ini sehingga aspek kelembagaan bank lahan meliputi organisasi atau entitas bank lahan dan kaidah / aturan main/ tata hubungan yang bersinergi untuk mencapai tujuan land banking. Adapun terdapat beberapa aspek yang termasuk kelembagaan bank lahan dalam penelitian ini yaitu bentuk dan struktur organisasi (Mubyarto, 1989; Israel, 1990), fungsi dan tujuan bank lahan (Alexander, 2011), tata hubungan organisasi dengan pihak lain / kerjasama (Rutten \& Hayami, 1989), kaidah formal (Mubyarto, 1989), tugas dan kewenangan organisasi (Israel, 1990)

\section{Pembiayaan}

Pembiayaan dalam konteks penelitian ini adalah segala sesuatu baik itu permodalan, penerimaan/ pendapatan, pengeluaran dan maupun mekanisme bank lahan. Keuangan publik berarti hal yang berhubungan dengan pembiayaan pada setiap kegiatan dan pengeluaran pemerintah (Hyman, 2011). Pembiayaan pembiayaan berkaitan dengan penerimaan sekaligus pengeluaran yang berkaitan dengan suatu program atau kegiatan (Undang-undang Nomor 17 Tahun 2003 tentang Keuangan Negara,)

\section{METODE PENELITIAN}

Penelitian ini merupakan penelitian kualitatif eksploratif. Terdapat dua cara pengumpulan data eksploratif yang dilakukan yaitu review dokumen dan wawancara Delphi. Review dokumen dilakukan untuk mengumpulkan informasi mengenai preseden praktek land banking di berbagai negara serta identifikasi peraturan perundangan. Review dokumen sangat membantu peneliti untuk dapat memahami bentuk, fungsi, tujuan, cara kerja, pembiayaan, dan karakteristik lainnya dari setiap land banking. Data dokumentasi ini merupakan data yang bisa dikumpulkan untu pembelajaran dari luar negeri karena apabila 
pengumpulan informasi dilakukan melalui wawancara ke berbagai negara tentu akan membutuhkan biaya yang sangat mahal.

Pengumpulan data berikutnya ialah wawancara mengadopsi pendekatan Delphi. Metode Delphi dipilih untuk digunakan karena dapat membentuk suatu konsep dari analisis jawaban narasumber terpilih yang diulang (Dalkey \& Helmer, 1962), (Delbecq, Van de Ven, \& Gustafson, 1975). Dalam membentuk konsep, peneliti didukung oleh pendapat-pendapat narasumber sehingga diharapkan hasil yang dicapai lebih objektif daripada bias sudut pandang peneliti. Selain wawancara tatap muka, proses pemberian pertanyaan atau kuesioner kepada panelis dilakukan dengan surat elektronik (Ludwig B. , 1997). Wawancara pada penelitian ini dilakukan dengan dua sesi. Sesi pertama bersifat terbuka untuk menggali pendapat dan sudut pandang narasumber. Sesi kedua dilakukan untuk meminta tanggapan narasumber atas pilihan konsep yang dihasilkan dari sesi pertama. Idealnya metode Delphi dilakukan sebanyak 5 sesi atau minimal 3 sesi (Cyphert \& Gant, 1971), (Brooks, 1979), Ludwig (1994, 1997), serta (Custer, Scarcella, \& Stewart, 1999). Namun dikarenakan keterbatasan sumber daya yang dimiliki peneliti, maka pada penelitian ini hanya dilakukan dua sesi.

Terdapat 8 narasumber yang berhasil diwawancarai dari 13 orang yang direncanakan. Pada sesi pertama terdapat 7 narasumber yang menjawab dan sesi kedua 3 narasumber dan 1 narasumber tambahan karena terlambat menjawab sesi pertama. Narasumber dipilih menurut kategori keahlian perencanaan, pemerintahan, hukum pertanahan, badan hukum dan korporasi. Ketujuh narasumber sesi pertama mewakili masing-masing kategori keahlian.

\section{HASIL DAN PEMBAHASAN}

Terdapat tiga bagian yang mewakili sasaran penelitian yang menunjukan tahapan hingga tercapai kesimpulan.

\section{Preseden Land Banking Berbagai Negara}

Berikut ini deskripsi singkat pembelajaran preseden penerapan land banking dari berbagai negara yaitu Amerika Serikat, Swedia, China dan India. Amerika Serikat dipilih untuk mempelajari praktek land banking yang dilakukan pada negara berorientasi pasar. Indonesia dalam pengembangan lahan prakteknya lebih cenderung berorientasi pasar seperti halnya di Amerika Serikat. China dipilih untuk mempelajari praktek land banking pada negara yang tidak mengakui kepemilikan individu. Swedia dalam hal ini Stockholm dipilih karena pencapaian luasan cadangan lahan yang sangat luas. Perlu kiranya melihat suatu penerapan land banking pada suatu negara yang berhasil mencadangkan lahan dengan sangat luas. Adapun India dipilih sebagai bank lahan yang mengimplementasikan rencana tata ruang kota. Hal ini sesuai dengan salah satu latar belakang penelitian ini yaitu adanya tantangan dalam implementasi rencana tata ruang yang berhadapan dengan dominasi kekuatan pasar.

Tabel 1 Rangkuman Pembelajaran Preseden Land Banking Berbagai Negara

\begin{tabular}{ll}
\hline Aspek & Rangkuman Pembelajaran Preseden Land Banking Berbagai Negara \\
\hline Latar & Indonesia, sesuai dengan latar belakang penelitian ini, menghadapi permasalahan dominasi \\
belakang, & kekuatan pasar dalam pengembangan lahan dalam perwujudan rencana tata ruang dan \\
fungsi dan & $\begin{array}{l}\text { kendala penyediaan lahan bagi pembangunan untuk kepentingan umum. Hal ini lebih } \\
\text { tujuan. } \\
\text { memiliki kesamaan dengan China, Swedia dan India. Indonesia tidak menghadapi } \\
\text { permasalahan banyaknya properti blighted di berbagai tempat seperti di Amerika Serikat, } \\
\text { hanya saja masih terdapat tanah-tanah yang terlantar/ tidak segera dimanfaatkan oleh } \\
\text { pemiliknya. Karena kebutuhan dan permasalahan yang menyerupai China, Swedia dan India , } \\
\text { maka pola penerapannya akan cenderung seperti ketiga negara tersebut. }\end{array}$ \\
\hline
\end{tabular}




\begin{tabular}{|c|c|}
\hline Aspek & Rangkuman Pembelajaran Preseden Land Banking Berbagai Negara \\
\hline $\begin{array}{c}\text { Bentuk } \\
\text { lembaga }\end{array}$ & 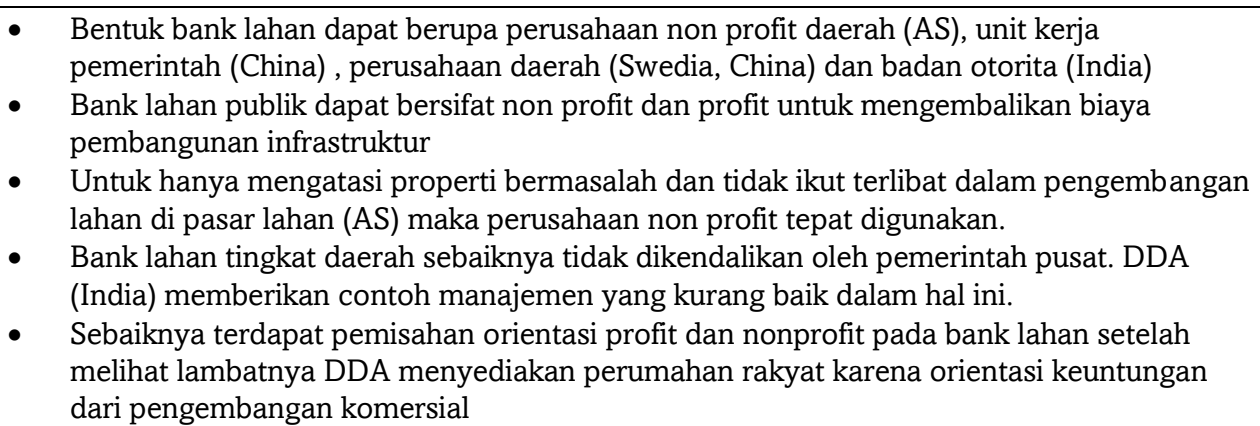 \\
\hline Kewenangan & $\begin{array}{l}\text { - Secara umum bank lahan memiliki kewenangan akuisisi, pengembangan lahan, dan } \\
\text { distribusi hak melalui HGB. } \\
\text { Terdapat kekhasan pada masing-masing negara seperti kewenangan terhadap pajak } \\
\text { properti di Amerika Serikat, kewenangan menyita di China, merevisi tarif HGB di } \\
\text { Stockholm, membuat masterplan dan meningkatkan status HGB menjadi hak milik di } \\
\text { Delhi. } \\
\text { - Kewenangan khusus yang dapat diadopsi di Indonesia ialah merevisi tarif HGB (Swedia), } \\
\text { dan meningkatkan status HGB menjadi Hak Milik (India). Hal ini karena pemegang HPL } \\
\text { berdasarkan peraturan perundangan dapat melakukan ini. } \\
\text { - } \\
\text { Adapun yang berkaitan dengan pajak (AS), apabila akan diadopsi maka harus melakukan } \\
\text { perubahan peraturan perundangan. } \\
\text { Kewenangan menyita /mencabut hak atas tanah (China) telah ada pada pemerintah } \\
\text { dengan UU No } 20 \text { tahun 1961 namun jarang digunakan karena tidak sesuai dengan } \\
\text { perkembangan hak asasi dan demokrasi. } \\
\text { Kewenangan membuat masterplan (India) tidak dapat diadopsi karena pemerintah daerah } \\
\text { memiliki kewenangan membuat RTRW dan RDTR. }\end{array}$ \\
\hline Permodalan & $\begin{array}{l}\text { Secara umum modal bank lahan berasal dari pemerintah baik pusat maupun daerah. } \\
\text { Walaupun pemerintah dianggap tidak memiliki cukup dana untuk permodalan, berdasarkan } \\
\text { preseden tersebut maka pemerintah tetap harus terlibat dalam permodalan bank lahan publik } \\
\text { yang dibentuknya. }\end{array}$ \\
\hline \multirow[t]{3}{*}{ Pemasukan } & Secara umum pendapatan bank lahan diperoleh dari penjualan / perolehan fee HGB properti. \\
\hline & $\begin{array}{l}\text { Khusus di Amerika Serikat karena memiliki kewenangan perpajakan, bank lahan } \\
\text { mendapatkan pendapatan dari perpajakan properti. }\end{array}$ \\
\hline & $\begin{array}{l}\text { Pola ini kecuali Amerika Serikat dapat diterapkan di Indonesia karena terbukti dapat } \\
\text { mendukung keberlanjutan bank lahan. }\end{array}$ \\
\hline Pengeluaran & $\begin{array}{l}\text { Pengeluaran bank lahan akan berkaitan dengan: } \\
\text { a. Operasional organisasi } \\
\text { b. Akuisisi lahan } \\
\text { c. Pengelolaan lahan/ properti yang disimpan } \\
\text { d. Pengembangan lahan/pembangunan properti } \\
\text { e. Pembangunan infrastruktur pendukung bagi kawasan land banking. }\end{array}$ \\
\hline
\end{tabular}

Sumber : Alexander, (2008, 2011), Anton (1975), Atmert (1987), Bao (2008), Delhi Development Act (1952), , Dong (2007), Heins \& Abdelazim (2014), Qian, (2015), Srirangan, (1997), Tang (2011), Yang, dkk (2005), Yang, dkk (2015), Zhang (2011), Zhang,dkk (2012), dan www.dda.org.in

\section{Peraturan perundangan dan Kebijakan}

Secara umum peraturan perundangan dan kebijakan pertanahan mendukung terbentuknya bank lahan. Berikut ini adalah temuan studi terkait identifikasi peraturan perundangan dan kebijakan pertanahan terhadap pembentukan bank lahan.

Berdasarkan identifikasi pada UUPA 1960, PP Nomor 40 Tahun 1996 dan Permenneg Agraria No 9 Tahun 1999, hak-hak atas tanah di Indonesia mendukung pembentukan bank lahan publik yaitu 
Tabel 2 Posisi Hak atas Tanah dengan Bank Lahan Publik di Indonesia

\begin{tabular}{|c|c|}
\hline Hak Atas lahan & Uraian \\
\hline $\begin{array}{l}\text { Hak Pengelolaan } \\
\text { (HPL) }\end{array}$ & $\begin{array}{l}\text { Bagian dari hak menguasai dari Negara. Berperan sebagai lembaga hukum bagi lahan } \\
\text { yang dikuasai bank lahan publik. HPL adalah satu-satunya hak atas tanah yang bersifat } \\
\text { publik diantara yang lain sehingga sesuai dengan tujuan pembentukan land banking } \\
\text { publik }\end{array}$ \\
\hline $\begin{array}{l}\text { Hak Guna Usaha } \\
\text { (HGU) }\end{array}$ & $\begin{array}{l}\text { Tidak memiliki hubungan hukum pada bank lahan. HGU hanya bisa dikaitkan kepada } \\
\text { penyelenggara pertanahan negara langsung yakni BPN karena bersumber langsung dari } \\
\text { hak menguasai dari negara (tanah negara). }\end{array}$ \\
\hline Hak Milik & $\begin{array}{l}\text { hak yang mutlak namun tidak bisa dipegang oleh bank lahan karena hanya bisa dipegang } \\
\text { oleh badan hukum tertentu. Hak milik berpeluang sebagai salah satu hak pada lahan } \\
\text { maupun properti yang didistribusikan oleh bank lahan. Namun pilihan untuk menerbitkan } \\
\text { hak milik tidak direkomendasikan peneliti karena akan mengurangi cadangan lahan yang } \\
\text { dimiliki oleh bank lahan }\end{array}$ \\
\hline $\begin{array}{c}\text { Hak Guna } \\
\text { Bangunan (HGB) }\end{array}$ & $\begin{array}{l}\text { salah satu hak pada lahan maupun properti yang didistribusikan oleh bank lahan } \\
\text { khususnya pada kawasan perkotaan. }\end{array}$ \\
\hline Hak Pakai & $\begin{array}{l}\text { salah satu hak pada lahan maupun properti yang didistribusikan oleh bank lahan. Hak } \\
\text { pakai dapat menggantikan HGU untuk lahan lahan pertanian. Apabila bank lahan akan } \\
\text { mendistribusikan penggunaan lahan untuk tujuan pertanian maka dapat digunakan Hak } \\
\text { Pakai karena dapat diterbitkan di atas HPL bank lahan sedangkan HGU tidak bisa. Hak } \\
\text { Pakai memiliki keleluasaan tujuan penggunaan dan jangka waktu yang dapat ditentukan } \\
\text { oleh penerbitnya hingga dapat dikuasai oleh WNA }\end{array}$ \\
\hline
\end{tabular}

Sumber : Analisis terhadap UUPA, PP No 40 Th 1996 dan PMNA No 9 Th 1999, 2017

Regulasi pengadaan tanah untuk kepentingan umum belum mencantumkan kegiatan pencadangan tanah/ land banking sebagai salah satu kepentingan umum pembangunan. Namun hal ini tidak menjadi hambatan bagi bank lahan apabila bentuknya berupa BUMD. BUMD tidak tercantum dalam pasal 1, angka 1 Ketentuan Umum, Undang-undang Nomor 2 Tahun 2012 sebagai salah satu kategori definisi instansi. Adapun yang dimaksud instansi pada Undang-undang tersebut ialah instansi yang memerlukan lahan dan harus mengikuti prosedur pengadaan tanah tersebut. Oleh karena BUMD tidak termasuk dalam instansi yang dimaksud UU No 2 tahun 2012, maka dalam melakukan akuisisi BUMD bank lahan bertindak secara perdata seperti perusahaan lainnya dalam membeli lahan. BUMD sebelum melakukan akuisisi harus mendapatkan izin lokasi dari pemerintah kabupaten/kota.

Menurut Kajian Arah Kebijakan Pengelolaan Pertanahan Nasional 2015-2019 dan RPJMN 2015-2019 Bidang Pertanahan, salah satu kebijakannya adalah pembentukan bank tanah. Hal ini menunjukkan bahwa pembentukan bank lahan didukung oleh kebijakan pemerintah

\section{Proses Metode Delphi}

$\underline{\text { Sesi Pertama }}$

Tabel 3 Ringkasan Simpulan Jawaban Narasumber Sesi Pertama

\begin{tabular}{cc}
\hline Aspek & \multicolumn{1}{c}{ Ringkasan Simpulan Jawaban } \\
\hline $\begin{array}{c}\text { Perlu tidaknya } \\
\text { lembaga khusus }\end{array}$ & $\begin{array}{c}\text { Sebagian besar menjawb perlu dibentuk lembaga yang melakukan land banking. Hanya } 2 \\
\text { narasumber yang tidak menyatakan perlu. }\end{array}$ \\
\hline $\begin{array}{c}\text { Permasalahan } \\
\text { mendasar terkait } \\
\text { land banking }\end{array}$ & $\begin{array}{l}\text { Oleh karena pemerintah belum mengakuisisi lahan, maka kebutuhan infrastruktur } \\
\text { tidak mudah untuk disediakan karena nilai lahan telah naik. Hal ini menyebabkan } \\
\text { pada suatu daerah yang berkembang menjadi kurang tertata dan kurang infrastruktur. } \\
\text { Ruang yang ideal sesuai kaidah perencanaan dengan infrastruktur yang lengkap } \\
\text { hampir selalu dapat diwujudkan oleh developer karena telah menguasai lahan-lahan. } \\
\text { Oleh karena banyak lahan yang dikuasai oleh beberapa developer saja, maka } \\
\text { kebijakan pemerintah pada prakteknya mengikuti arus pasar. }\end{array}$ \\
\hline
\end{tabular}




\begin{tabular}{|c|c|}
\hline Aspek & Ringkasan Simpulan Jawaban \\
\hline & $\begin{array}{l}\text { Walaupun demikian, setiap daerah memiliki permasalahan dan kondisi pertanahan } \\
\text { yang berbeda-beda. }\end{array}$ \\
\hline $\begin{array}{l}\text { Tujuan dan } \\
\text { Fungsi yang } \\
\text { seharusnya ada } \\
\text { pada Bank Lahan } \\
\text { di Indonesia }\end{array}$ & $\begin{array}{l}\text { Menyediakan lahan untuk kepentingan publik } \\
\text { Menyediakan perumahan rakyat untuk kesejahteraan rakyat } \\
\text { Manajemen lahan untuk meningkatkan produktifitas lahan } \\
\text { Mewujudkan keadilan bagi seluruh stakeholder sehingga terwujud sebesar-besar } \\
\text { kemakmuran rakyat } \\
\text { Menyimpan lahan secara jangka panjang untuk menjamin ketersediaan lahan dan } \\
\text { mengimbangi penguasaan lahan oleh develper }\end{array}$ \\
\hline $\begin{array}{l}\text { Kendala dalam } \\
\text { pembentukan } \\
\text { bank lahan publik }\end{array}$ & $\begin{array}{l}\text { Kemampuan manajerial pemerintah diragukan untuk mengelola langsung bank lahan } \\
\text { Pemerintah tidak memiliki modal yang cukup karena banyaknya urusan yang } \\
\text { menjadi tugasnya } \\
\text { Adanya resiko campur tangan politik terhadap bank lahan untuk kepentingan pendek } \\
\text { pemilihan khususnya bila bank lahan adalah badan usaha milik pemerintah } \\
\text { Pemerintah daerah belum memiliki visi untuk menyediakan lahan bagi perumahan } \\
\text { rakyat }\end{array}$ \\
\hline $\begin{array}{l}\text { Usulan Bentuk } \\
\text { Kelembagaan }\end{array}$ & $\begin{array}{l}\text { BLU Bank Lahan di bawah Kementerian Agraria dan Tata Ruang/BPN } \\
>\quad \text { Perusahaan tingkat daerah model Public Private People Partnership }\end{array}$ \\
\hline Pembiayaan & $\begin{array}{l}\text { Dalam menyediakan lahan publik, bisa saja tidak menggunakan modal tapi } \\
\text { menggunakan regulasi sehingga pemerintah memperoleh lahan. } \\
\text { Modal dan pembiayaan bank lahan dapat berasal dari APBN, APBD, swasta, } \\
\text { pinjaman bank maupun tanah masyarakat tergantung pada bentuk lembaga. }\end{array}$ \\
\hline
\end{tabular}

Sumber : Analisis wawancara, 2017

Berdasarkan preseden, literatur, peraturan perundangan dan jawaban para narasumber, peneliti membuat kompilasi alternatif konsep sesi pertama untuk dimintai tanggapan narasumber pada sesi kedua. Berikut ini adalah alternatif konsep singkat sesi pertama.

\section{BLU Bank Lahan di bawah BPN}

Oleh karena konsep ini dinyatakan secara utuh oleh narasumber maka peneliti coba untuk tawarkan kembali untuk diberi tanggapan oleh para narasumber. Adapun deskripsi dari konsep ini adalah sebagai berikut

Tabel 4 Ringkasan Konsep BLU Bank Lahan pada Sesi Pertama

\begin{tabular}{|c|c|}
\hline Aspek & Uraian \\
\hline $\begin{array}{l}\text { Bentuk } \\
\text { Lembaga }\end{array}$ & $\begin{array}{l}\text { Berbentuk unit kerja pemerintah badan layanan umum di bawah struktur organisasi } \\
\text { Kementerian Agraria dan Tata Ruang/ BPN. Berada pada setiap kantor pertanahan seluruh } \\
\text { Indonesia sehingga memiliki jangkauan yang luas. Memiliki dewan pengawas yang terdiri } \\
\text { dari unsur Bappenas, KemenPuPeRa, Kementerian Keuangan, dan BPN }\end{array}$ \\
\hline $\begin{array}{l}\text { Tujuan } \\
\text { Fungsi }\end{array}$ & $\begin{array}{l}\text { 1. Menyediakan lahan untuk pembangunan kepentingan umum baik oleh pemerintah } \\
\text { pusat maupun pemerintah daerah. Prioritas pembangunan ialah untuk perumahan } \\
\text { rakyat (murah), infrastruktur, industri dll. } \\
\text { 2. Tidak boleh bertujuan profit namun bisa sekedar hanya untuk operasional sdm dan } \\
\text { manajemen } \\
\text { 3. Manajemen lahan pada aset bank lahan dengan cara leasing (menyewakan) jangka } \\
\text { panjang secara periodik. }\end{array}$ \\
\hline Dasar Hukum & $\begin{array}{l}\text { 1. UU No } 17 \text { tahun } 2003 \text { tentang Keuangan Negara } \\
\text { 2. UU no } 1 \text { tahun } 2004 \text { tentang Perbendaharaan Negara } \\
\text { 3. UU no } 15 \text { tahun } 2004 \text { tentang Pemeriksaan Pengelolaan dan Tanggung Jawab } \\
\text { Keuangan Negara } \\
\text { 4. UU No } 2 \text { Tahun } 2012 \text { tentang Pengadaan Tanah bagi Pembangunan untuk Kepentingan } \\
\text { Umum, namun perlu direvisi dengan menambahkan bank lahan sebagai tambahan pada }\end{array}$ \\
\hline
\end{tabular}




\begin{tabular}{|c|c|}
\hline & $\begin{array}{l}\text { kriteria kepentingan umum (pasal 10) } \\
\text { 5. PP No } 23 \text { tahun } 2005 \text { tentang Pengelolaan Keuangan BLU } \\
\text { 6. PP no } 74 \text { tahun } 2012 \text { tentang Perubahan PP No } 23 \text { tahun } 2005 \text { tentang Pengelolaan } \\
\text { Kuangan BLU }\end{array}$ \\
\hline Stakeholder & $\begin{array}{l}\text { Stakeholder utama adalah Kementerian Agraria dan Tata Ruang/Badan Pertanahan } \\
\text { Nasional. Selain itu terdapat stakeholder pendukung yaitu Bappenas, Kementerian } \\
\text { Keuangan, Kementerian Pekerjaan Umum dan Perumahan Rakyat yang berperan dalam } \\
\text { dewan pengawas. }\end{array}$ \\
\hline $\begin{array}{l}\text { Modal dan } \\
\text { Pembiayaan }\end{array}$ & $\begin{array}{l}\text { Modal berasal dari APBN. Adapun pembiayaannya dapun pembiayaannya dapat bersumber } \\
\text { dari : } \\
\text { 1. Hasil penjualan lahan kepada pemerintah pusat dan BUMN yang kemudian dicatat } \\
\text { sebagai aset negara. } \\
\text { 2. Hasil penyewaan jangka panjang pada lahan yang dikuasai kepada pemerintah, BUMN, } \\
\text { BUMD maupun swasta } \\
\text { 3. Kerjasama dengan pihak swasta } \\
\text { 4. Penerimaan mengikat maupun tidak mengikat lain }\end{array}$ \\
\hline
\end{tabular}

2. Perusahaan tingkat daerah dengan model Public Private People Partnership Konsep ini merupakan kompilasi dari jawaban narasumber, preseden, literatur dan peraturan perundangan. Deskripsi dari konsep ini adalah sebagai berikut

Tabel 5 Ringkasan Konsep Perusahaan PPPP pada Sesi Pertama

\begin{tabular}{|c|c|}
\hline Aspek & Uraian \\
\hline $\begin{array}{l}\text { Bentuk } \\
\text { Lembaga }\end{array}$ & $\begin{array}{l}\text { Merupakan perusahaan perseroan yang dimiliki oleh } 4 \text { pihak yaitu pemerintah, swasta, } \\
\text { masyarakat kontributor dan masyarakat permodalan /bank pembangunan daerah. }\end{array}$ \\
\hline $\begin{array}{l}\text { Tujuan dan } \\
\text { Fungsi }\end{array}$ & $\begin{array}{l}\text { 1. Meningkatkan produktifitas lahan, bank lahan tidak boleh menyimpan lahan namun } \\
\text { justru menjadi terlantar. Oleh karena itu bank lhan berperan pula sebagai developer. } \\
\text { 2. Menyediakan lahan untuk kepentingan umum. Harus ada lahan yang dialokasikan } \\
\text { untuk kepentingan publik (BRD) } \\
\text { 3. Membangun infrastruktur dalam rangka menata kawasan. } \\
\text { 4. Menyediakan Perumahan Rakyat } \\
\text { 5. Memberikan keadilan kepada seluruh stakeholder }\end{array}$ \\
\hline Dasar Hukum & $\begin{array}{l}\text { 1. UU No } 40 \text { tahun } 2007 \text { tentang Perseroan Terbatas } \\
\text { 2. UU No } 2 \text { Tahun } 2012 \text { tentang Pengadaan Tanah bagi Pembangunan untuk Kepentingan } \\
\text { Umum } \\
\text { 3. PP No } 40 \text { tahun } 1996 \text { tentang Hak Guna Usaha, Hak Guna Bangunan dan Hak Pakai } \\
\text { Atas Tanah } \\
\text { 4. Peraturan Menteri Negara Agraria Nomor } 9 \text { Tahun } 1999 \text { Tata Cara Pemberian Dan } \\
\text { Pembatalan Hak Atas Tanah Negara dan Hak Pengelolaan } \\
\text { 5. Peraturan Presiden tentang Bank Lahan (perlu dibuat) } \\
\text { 6. Peraturan daerah tentang pembentukan bank lahan (perlu dibuat) } \\
\text { 7. AD/ART pendirian perusahaan }\end{array}$ \\
\hline Stakeholder & $\begin{array}{l}\text { Bank lahan dengan model PPPP dilembagakan dengan bentuk perseroan terbatas. Adapun } \\
\text { pemegang saham perseroan terdiri dari } 4 \text { pihak yaitu: } \\
\text { 1. Pemerintah dapat berupa pemerintah kabupaten/kota saja ataupun terdapat peran } \\
\text { pemerintah propinsi maupun pusat. Hal ini tergantung pada kondisi dan situasi } \\
\text { pertanahan di daerah tersebut. } \\
\text { 2. Masyarakat Kotributor Lahan, merupakan masyarakat pemegang hak atas lahan } \\
\text { sebelum dibentuk bank lahan pada kesatuan kawasan yang diprioritaskan oleh } \\
\text { pemerintah dae rah maupun di luar kawasan tersebut atas dasar sukarela. } \\
\text { 3. Swasta perusahaan developer, merupakan perusahaan developer swasta yang memiliki } \\
\text { pengalaman dan modal yang kuat. Pihak ini dapat berupa konsorsium pengembang- } \\
\text { pengembang lokal. Syarat bergabung dalam bank lahan adalah memenuhi kriteria } \\
\text { lelang yang berkaitan dengan pengalaman, keahlian dan permodalan. } \\
\text { 4. Masyarakat permodalan yang pada awalnya dapat diisi oleh bank pembangunan daerah } \\
\text { setempat ataupun bank pemerintah nasional }\end{array}$ \\
\hline $\begin{array}{l}\text { Modal dan } \\
\text { Pembiayaan }\end{array}$ & $\begin{array}{l}\text { Modal berasal dari pemerintah, swasta dan lahan masyarakat. Contohnya pemerintah } \\
\text { mendapat saham } 20 \% \text { dengan mengganti rugi } 2 / 8 \text { nilai lahan masyarakat, } 10 \% \text { dari } \\
\text { komitmen membangun infrastruktur dan } 10 \% \text { dari setoran modal tunai sehingga totalnya } \\
40 \% \text {. Swasta mendapatkan saham } 20 \% \text { dengan mengganti rugi } 2 / 8 \text { nilai lahan masyarakat, }\end{array}$ \\
\hline
\end{tabular}




\begin{tabular}{|c|c|}
\hline Aspek & Uraian \\
\hline & $\begin{array}{l}\text { masyarakat permodalan mendapatkan saham } 10 \% \text { dari mengganti rugi } 1 / 8 \text { nilai lahan } \\
\text { masyarakat. Masyarakat kontributor lahan sendiri masih memiliki } 3 / 8 \text { nilai lahan yang } \\
\text { disetorkan sebagai inbreng untuk mendapatkan saham } 30 \% \text {. }\end{array}$ \\
\hline & Adapun Pembiayaan bank lahan PPPP ini berasal dari berbagai sumber yaitu: \\
\hline & 1. Keuntungan pengembangan lahan pada kawasan komersial, industri dan perumahan. \\
\hline & 2. Alokasi dana pusat yang ditujukan untuk menyediaan perumahan rakyat \\
\hline & $\begin{array}{l}\text { 3. Uang pemasukan dari pemanfaatan aset bank lahan oleh pihak lain termasuk } \\
\text { pemerintah pusat atau BUMN yang memerlukan lahan untuk pembangunan } \\
\text { kepentingan umum pada skala yang luas }\end{array}$ \\
\hline & $\begin{array}{l}\text { 4. Pembangunan sarana prasarana oleh pemerintah daerah yang bukan merupakan } \\
\text { kewajiban penyertaan modal. }\end{array}$ \\
\hline & $\begin{array}{l}\text { 5. Pinjaman bank melalui penjaminan sebagian aset bank lahan yang diterbitkan HGB atas } \\
\text { nama bank lahan di atas HPL Bank Lahan. }\end{array}$ \\
\hline & 6. Hasil investasi bank lahan pada sektor lain \\
\hline
\end{tabular}

\section{$\underline{\text { Sesi Kedua }}$}

Tabel 6 Ringkasan Tanggapan narasumber pada Sesi Kedua

\begin{tabular}{|c|c|c|}
\hline $\begin{array}{l}\text { Tanggapan terhadap Konsep } \\
\text { BLU Bank Lahan di Bawah BPN }\end{array}$ & $\begin{array}{c}\text { Tanggapan terhadan } \\
\text { Konsep Perusahaan tingkat Daerah } \\
\text { model PPPP }\end{array}$ & Tanggapan Umum \\
\hline $\begin{array}{l}\text { Mekanisme } \text { BLU } \\
\text { mendistribusikan lahan } \\
\text { nonprofit termasuk kepada swasta } \\
\text { sedangkan melalui pembebasan lahan } \\
\text { yang murah hanya akan memposisikan } \\
\text { bank lahan sebagai lembaga yang } \\
\text { mempermudah penyediaan lahan saja. } \\
\text { (SD) }\end{array}$ & $\begin{array}{l}\text { Bentuknya boleh BUMD (mayoritas } \\
\text { pemda) boleh Perseroan (swasta) } \\
\text { (SD) }\end{array}$ & $\begin{array}{l}\text { Konsep kasiba/lisiba dapat diadopsi } \\
\text { sebagai cara land banking (AT) }\end{array}$ \\
\hline $\begin{array}{l}\text { Pola yang seperti itu bertentangan } \\
\text { dengan pasal } 33 \text { UUD } 1945 \text { (SD) }\end{array}$ & $\begin{array}{l}\text { Pentingnya membagi keuntungan } \\
\text { diantara pemerintah, swasta dan } \\
\text { masyarakat agar tercipta keadilan } \\
\text { (SD) }\end{array}$ & $\begin{array}{l}\text { Pentingnya keterlibatan bank lahan } \\
\text { yang otonom dalam penyediaan } \\
\text { perumahan khususnya perumahan } \\
\text { rakyat yang akhirnya dapat } \\
\text { mengendalikan harga properti di pasar } \\
\text { (AT) }\end{array}$ \\
\hline $\begin{array}{l}\text { BLU memiliki kelebihan menjangkau } \\
\text { seluruh wilayah Indonesia (HI), (FOS) }\end{array}$ & $\begin{array}{l}\text { Perlu memposisikan bank lahan } \\
\text { secara tepat karena terdapat interes } \\
\text { swasta dan publik dalam model } \\
\text { PPPP. Dapat dilakukan dengan } \\
\text { penentuan tanah-tanah publik dan } \\
\text { tanah-tanah privat. (FOS) }\end{array}$ & $\begin{array}{l}\text { Hak pengelolaan tepat sekali dipegang } \\
\text { oleh bank lahan }(\mathrm{HI})\end{array}$ \\
\hline $\begin{array}{l}\text { BLU bank lahan sifatnya umum tidak } \\
\text { hanya perumahan (HI) }\end{array}$ & $\begin{array}{l}\text { Model PPPP akan efektif dalam } \\
\text { menyediakan kasiba/lisiba (HI) }\end{array}$ & \\
\hline
\end{tabular}

Berdasarkan analisis jawaban/ tanggapan para narasumber maka Perusahaan tingkat daerah dengan model PPPP menjadi pilihan konsep karena

1. Terdapat satu narasumber yang menyatakan ketidaksetujuan dan kelemahan BLU di bawah Bank Lahan

2. Dua narasumber menyatakan bank lahan mengadopsi konsep Kasiba yang hanya dapat dilaksanakan dengan alternatif konsep kedua

3. Satu narasumber menyatakan pengelolaan bank lahan yang bersifat otonom yang terdapat pada konsep kedua dan tidak pada konsep pertama

4. Masukan yang diberikan pada konsep kedua tidak bersifat prinsip

5. Seluruh narasumber sepakat pada falsafah UUD 1945 pasal 33 bahwa Bank Lahan bertujuan untuk memberikan sebesar-besar kemakmuran rakyat. 
6. Penggagas BLU di bawah BPN tidak memberikan tanggapan pada sesi kedua.

7. Konsep BLU di bawah BPN memiliki beberapa kelemahan yaitu merupakan bagian dari struktur pemerintah dan intervensi langsung birokrasi pada pemilikan lahan publik dikhawatirkan menyebabkan kinerjanya lamban dan kurang responsif terhadap kebutuhan penggunaan lahan yang justru dapat menyebabkan inefisiensi (Bryant, 1976 dan Clawson, 1971) serta yang disebutkan oleh narasumber.

\section{Konsep Akhir}

Konsep bank lahan publik yang terpilih adalah Perusahaan tingkat daerah dengan model PPPP. Namun dikarenakan terdapat 2 kelemahan pada konsep ini yaitu kendala pemilikan modal untuk memegang HPL dan adanya campuran kepentingan publik dan privat, maka konsep ini dimodifikasi menggunakan pendekatan konsep Kasiba/Lisiba. Konsep akhir pada sesi kedua menjadi dua perusahaan yang saling terkait. Perusahaan pertama merupakan badan usaha milik daerah dengan kepemilikan sepenuhnya milik pemerintah yang mengelola lahan publik. Perusahaan kedua merupakan perusahaan dengan model PPPP yang berorientasi profit.

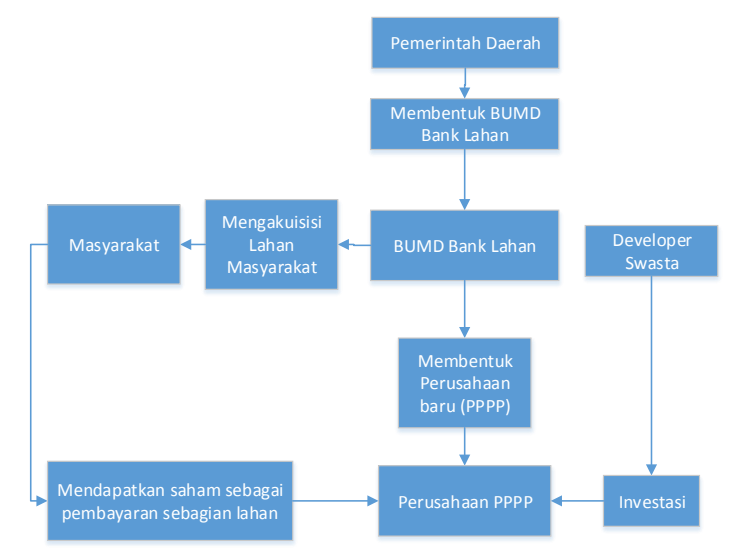

Sumber : Analisis, 2017

Gambar 1. Konsep Akhir Kelembagaan Bank Lahan Publik

Terdapat perbedaan antara konsep akhir dengan alternatif konsep kedua pada sesi pertama. Perbedannya hanya terletak pada bentuk lembaga dan fungsi bank lahan yang terbagi pada masing-masing perusahaan. Adapun aspek dasar hukum tidak mengalami perubahan.

Tabel 7 Ringkasan Modifikasi Kelembagaan Konsep Akhir pada Sesi Kedua

\begin{tabular}{ll}
\hline \multicolumn{1}{c}{ Aspek } & \multicolumn{1}{c}{ Uraian } \\
\hline Bentuk & $\begin{array}{l}\text { Dua perusahaan tingkat daerah. Perusahaan utama dimiliki oleh pemerintah yang disebut } \\
\text { Lembaga }\end{array}$ \\
& $\begin{array}{l}\text { BUMD Bank Lahan. Perusahaan kedua menggunakan model PPPP yang bersifat profit. } \\
\text { Perusahaan PPPP dimiliki oleh BUMD Bank Lahan, Pemerintah daerah, Masyarakat } \\
\text { Kontributor dan Swasta. }\end{array}$ \\
\hline Stakeholder & Pemerintah daerah, BUMD Bank Lahan, Masyarakat Kontributor Lahan dan Swasta \\
\hline Tujuan dan & $\begin{array}{l}\text { Tujuan dan fungsi BUMD Pemegang HPL ialah } \\
\text { Fungsi }\end{array}$ \\
& $\begin{array}{l}\text { 1. Menyimpan dan menyediakan lahan untuk kepentingan umum. } \\
\text { 2. Membangun infrastruktur dalam rangka menata kawasan. Fungsi ini dijalankan oleh } \\
\text { BUMD bersama pemerintah daerah }\end{array}$ \\
\hline
\end{tabular}




\begin{tabular}{|c|c|}
\hline & $\begin{array}{l}\text { Tujuan dan fungsi Perusahaan Profit PPPP ialah } \\
\text { 1. Meningkatkan produktifitas lahan, bank lahan tidak boleh menyimpan lahan namun } \\
\text { justru menjadi terlantar. Bank Lahan berperan pula sebagai developer. } \\
\text { 2. Membagi keuntungan pengembangan lahan kepada stakeholder yang pada akhirnya } \\
\text { untuk kepentingan umum. }\end{array}$ \\
\hline $\begin{array}{l}\text { Modal dan } \\
\text { Pembiayaan }\end{array}$ & $\begin{array}{l}\text { Modal BUMD Bank Lahan sepenuhnya dari Pemerintah Daerah yang dapat diperoleh dari } \\
\text { pinjaman jangka panjang } \\
\text { Modal Perusahaan Profit PPPP berasal dari investasi swasta, inbreng lahan BUMD dan } \\
\text { Masyarakat Kontributor serta komitmen pemerintah daerah dalam membangun } \\
\text { infrastruktur pendukung. }\end{array}$ \\
\hline
\end{tabular}

BUMD Bank Lahan mendapatkan keuntungan dari inbreng lahan pada Perusahaan Profit PPPP. Keuntungan tersebut digunakan untuk mendukung operasional BUMD Bank Lahan dalam mengelola lahan bagi kepentingan umum termasuk penyediaan perumahan rakyat.

Sumber : Analisis, 2017

\section{KESIMPULAN}

Bentuk kelembagaan bank lahan publik yang dihasilkan dari proses penelitian ini ialah dua perusahaan pada tingkat daerah yang saling terkait secara bersama-sama berperan sebagai bank lahan. Perusahaan pertama merupakan perseroan BUMD yang memegang HPL kawasan land banking bertugas mengelola lahan untuk kepentingan publik dan penyediaan perumahan rakyat. Perusahaan kedua merupakan perseroan berorientasi profit dengan model PPPP sehingga keuntungan pengembangan lahan dibagi kepada berbagai pihak yaitu BUMD Bank Lahan, swasta investor, masyarakat kontributor lahan dan pemerintah kabupaten/kota. Pembagian keuntungan ini secara tidak langsung akan mendukung penyelenggaraan layanan kepentingan publik baik oleh BUMD bank lahan dalam penyediaan perumahan rakyat maupun pemerintah kabupaten/kota dalam pembangunan infrastruktur.

Berdasarkan penelitian ini direkomendasikan kepada pemerintah untuk tidak menggunakan bentuk BLU sebagai bank lahan di bawah BPN karena hal ini dikhawatirkan justru menyebabkan inefisiensi dalam penggunaan lahan seperti yang disebutkan dalam teori maupun jawaban narasumber. Usulan konsep hasil penelitian ini dapat saja digunakan sebagai bentuk kelembagaan bank lahan namun masih memerlukan beberepa penelitian lanjutan. Penelitian lanjutan yang perlu dilakukan ialah melakukan kajian kriteria dan indikator kelayakan BUMD-Bank Lahan dengan analisis kelayakan finansial pada suatu daerah tertentu akan kemungkinan penerapannya

\section{UCAPAN TERIMA KASIH}

Peneliti mengucapkan terima kasih kepada pihak-pihak yang telah mendukung pelaksanaan penelitian ini. Terima kasih disampaikan secara khusus kepada para narasumber Delphi yaitu Bap ak Ir. Bernardus R. Djonoputro (Ketua Ikatan Ahli Perencana/ IAP), Bapak. Dr. Ir. Budi Situmorang, MURP (Dirjen Tata Ruang, Kementerian ATR), Bapak Prof. Dr. Felix Oentoeng Soebagjo, SH., LLM (Ahli hukum perdata, konsultan hukum Oentoeng Suria \& Partners), Prof. Arie Sukanti Hutagalung, SH, MLI sebagai ahli hukum pertanahan, Bapak. Dr. Ir. Son Diamar, MSc sebagai ahli pemerintahan, Bapak Uke Muhammad Hussein, S.Si, MPP (Direktur Tata Ruang dan Pertanahan, Bappenas),Bapak Hery Irwanto (Direktur Pertanahan dan Hukum PT. Perumnas) dan Bapak Ali Tranghanda dari Indonesia Property Watch.. 


\section{DAFTAR PUSTAKA}

Alexander, F. S. (2008). Land banking as Metropolitan Policy. Brookings: Blueprint for American Prosperity.

Alexander, F. S. (2011). Land Banks and Land banking. Michigan: Center for Community Progress.

Anton, T. J. (1975). Governing Greater Stockholm : A Study of Policy Development and System Change. Berkeley: University of California Press.

Armanda, A. (2013). Ekonomi Politik : Seyngketa Aset Antara Yayasan Kas Surabaya dengan Pemerintah Kota Surabaya. Jurnal Politik Muda Vol 3, No. 3, Agustus-Desember , 396-411.

Atmert, T. (1987). Land banking in Stockholm. Habitat Intl. Vol 1 I. No 1 , 37-55.

Bao, H. (2008). Policies Supply and Institution Organization : Fieldwork on the Regulation Evolvement of Land Acquisition. Beijing: Economy and Management Press.

Brooks, K. W. (1979). Delphi Technique: Expanding Applications. North Central Association Quarterly, 54 (3) , 377-385.

Carr, J., \& Smith, L. (1975). Public Land banking and the Price of Land. Journal Land Economics 51 , 4:316-30.

Custer, R. L., Scarcella, J. A., \& Stewart, B. R. (1999). The mdified Delphi Technique: A Rotational modification. Journal of Vocational and Technical Education 15(2) , 1-10.

Cyphert, F. R., \& Gant, W. L. (1971). The Delphi Technique A Case Study. Phi Delta Kappan 52 , 272-273.

Dalkey, N., \& Helmer, O. (1962). An Experimental Application of The Delphi Method to The Use of Experts. California: The RAND Corporation.

(2014-2015). DDA Annual Report. Delhi: Delhi Development Authority.

DDA at a Glance. (2016). Dipetik September 10, 2016, dari Delhi Development Authority: http://dda.org.in/ddanew/dda_at_glance.aspx

de Wit, J. (2006). Revitalizing Blighted Communities with Land Banks. Dipetik April 23, 2016, dari University of Michigan: http://www.umich.edu/ econdev/landbank/

Delbecq, A. L., Van de Ven, A. H., \& Gustafson, D. H. (1975). Group Techniques for Program Planning. Glenview Illinois: Scott, Foresman and Co.

Delhi Development Act. (1957).

Devoy, R. S., \& Rodrungrung.(tanpa tahun), C. Basic Land banking concepts and their application to low cost housing in Thailand.

Dong, W. (2007). Problems and Solutions in the land Reserve System of Medium and Small Cities. Guang Dong Tu Di Ke Xue 6 (Chinese) , 8-12.

Evans, A. W. (2004). Economics, Real Estate \& The Supply of Land. Oxford: Blackwell Publishing.

Hamilton, S. W., \& Baxter, D. E. (1977). Government Ownership and the Price of Land,. Dalam L. B. Smith, \& M. Walker, Public Property? The Habitat Debate Continued (hal. 75-118). Vancouver BC: Fraser Institute.

Harrison, F. (2010). The Inquest. London: Bookforce.

Heins, P., \& Abdelazim, T. (2014). Take it to The Bank : How Land Banks Are Streghtening America's Neighborhoods. Michigan: Center for Community Progress.

Hermit, H. (2009). Teknik Penaksiran Harga Tanah Perkotaan: Teori dan Praktek Penilaian Tanah. Bandung: CV. Mandar Maju.

Hsu, C.-C., \& Sandford, B. A. (2007). The Delphi Technique: Making Sense of Consensus. Practical Assessment, Research \& Evaluation Vol 12(10) .

Hutagalung, A. S. (2011). Seputar Hak Pengelolaan. Yogyakarta: STPN Press.

Hyman, D. N. (2011). Public Finance , A Contemporary Application of Theory to Policy, 10th Edition. Mason: Cengage Learning.

IDB. (2010). Kendala Kritis bagi Pembangunan Infrastruktur. Islamic Development Bank.

Israel, A. (1990). Institutional Developmetn. Washington D.C.: World Bank.

Jacobs, H. M., \& van der Krabben, E. (2013). Public land develpoment as a strategic tool for development : Reflections on the Dutch Experience. Land Use Policy Vol. 30 , 774-783.

Jacobs, J. M. (1996). Essential Assessment Criteria for Physical Education Teacher Education Programs, Disertasi. Morgantown: West Virginia University.

Janis, I. L. (1949). The Problem of Validating Content Analysis. New York: George W. Stewart. 
Jones, C. G. (1975). A Delphi Evaluation of Agreement between Organization. Dalam H. A. Linstone, \& M. Turoff (Eds), The Delphi Method: Techniques and Applications (hal. 160-167). Reading, MA: AddisonWesley Publishing Company.

Kehoe, D., D., M., Proudfoot, S. B., \& Roberts, N. A. (1976). Public Land Ownership Frameworks for Evaluation. Massachusetts: Lexington Books.

Kivell, P. (1993). Land and The City. London: Routledge.

Kompas. (2014, April 8). Reforma Agraria Mendesak. Kompas.

Kriyantono, R. (2006). Teknis Praktis Riset Komunikasi. Jakarta: Kencana.

Limbong, B. (2013). Bank Tanah. Jakarta: Margaretha Pustaka.

Lindzey, G., \& Aronson (Eds), E. (1969). Handbook of Social Psychology 3rd ed. New Yorl: Random House.

Ludwig, B. G. (1994). Internationalizing Extension: An Exploration of The Characteristics Evident in A State University Extension System That Achieves Internalization. Disertasi. Colombus: The Ohio State Univesity.

Ludwig, B. (1997). Predicting the Future Have you Considered using the Delphi Methodology? Journal of Extension 35(5) www.joe.org/joe/1997october/tt2.html. , 1-4.

Meyer, J. (1992). Rethinking The Outlook of Colleges Whose Roots have been in Agriculture. Davis, CA: University of California.

Mubyarto. (1989). Pengantar Ekonomi Pertanian. Jakarta: LP3ES.

Qian, Z. (2015). Land Acquisition Compensation in post-Reform China ; Evolution, Structure and Challenges in Hangzhou. Land Use Policy 40 , 250-257.

Rajack, R. (2007). Does the Ownership and Management of Public Land Matter to Land Market Outcomes? 4th International Urban Research Symposium. Washington D.C: World Bank.

Rutten, V. W., \& Hayami, Y. (1984). Toward A Theory of Induced Institutional Innovation. Minneapolis: Univers ity of Minnesota.

Srirangan, K. (1997). Land Policies in Delhi: Their Contribution to Unauthorised Land Development. Disertasi. London: University of London.

Strauss, A., \& Corbin, J. M. (1998). Basics of Qualitative Research. California: SAGE Publication.

Sudianto, A. (2014). The Role of Market Forces and Spatial Planning on Land Development. Case Study : Jakarta, Indonesia and Hongkong. Tesis. Bandung: Institut Teknologi Bandung.

Tang, J. (2011). Review and Discussion on Land Acquisition Reform. China Land Sci. 25 , 3-7.

UNESCAP. (1993). Municipal Land Management in Asia : A Comparative Study. United Nations Economic and Social Commission for Asia and the Pasific.

Yang, L. J., Q., H. C., G., L., Y., G., \& X.L., T. (2005). The Analysis of Development of Land-banking Organizations in China. Economic Geography 25 , 557-561.

Yang, Z., Ren, R., Liu, H., \& Zhang, H. (2015). Land Leasing and Local Government Behaviour in China: Evidence from Beijing. Urban Studies Vol. 52(5) , 841-856.

Yin, R. K. (2011). Qualitative Research from Start to Finish. New York: The Guilford Press.

Zhang, Q., Zhang, W., Li, M., Huang, Q., \& Li, F. (2012). Land banking ; A Mechanism for Urban Sustainable Development in China. AMBIO 41, DOI 10.1007/sI3280-012-0297-y , 904-906.

Zhang, Y. (2011). Institutional Sources of Reform: The Diffusion of Land banking Systems in China. Management and Organization Review, doi: 10.1111/j.1740-8784.2011.00256.x .

Zulkaidi, D., Sari, M. K., \& Navastara, A. M. (2007). Dampak Pengembangan Lahan Skala Besar terhadap Pasar Lahan dan Transformasi Peri-urban Kota Jakarta. Research Series UPDRG. Bandung: Institut Teknologi Bandung 